\title{
Microribonucleic acid dysregulations in children and adolescents with obsessive-compulsive disorder
}

This article was published in the following Dove Press journal:

Neuropsychiatric Disease and Treatment

14 July 2015

Number of times this article has been viewed

\author{
Hasan Kandemir ${ }^{1}$ \\ Mehmet Emin Erdal ${ }^{2}$ \\ Salih Selek ${ }^{3}$ \\ Özlem İzci Ay ${ }^{2}$ \\ İbrahim Fatih Karababa ${ }^{4}$ \\ Mustafa Ertan $\mathrm{Ay}^{2}$ \\ Sultan Basmacı Kandemir ${ }^{5}$ \\ Șenay Görücü Yılmaz \\ Suat Ekinci ${ }^{6}$ \\ Bahar Tașdelen ${ }^{7}$ \\ Hüseyin Bayazit ${ }^{4}$ \\ 'Department of Child and Adolescent \\ Psychiatry, Faculty of Medicine, \\ Harran University, Șanlıurfa, Turkey; \\ ${ }^{2}$ Department of Medical Biology and \\ Genetics, Faculty of Medicine, Mersin \\ University, Mersin, Turkey; ${ }^{3}$ Harris \\ County Psychiatric Center, University \\ of Texas Health Science Center at \\ Houston, TX, USA; ${ }^{4}$ Department \\ of Psychiatry, Faculty of Medicine, \\ Harran University, Șanlıurfa, Turkey; \\ ${ }^{5}$ Department of Psychiatry, Balıklıgöl \\ State Hospital, Șanlıurfa, Turkey; \\ ${ }^{6}$ Department of Psychiatry, Balıklı \\ Rum Hospital, Istanbul, Turkey; \\ ${ }^{7}$ Department of Biostatistics, Faculty \\ of Medicine, Mersin University, Mersin, \\ Turkey
}

Correspondence: Hasan Kandemir Department of Child and Adolescent Psychiatry, Faculty of Medicine, Harran University, Yemisehir, 63100 Șanliurfa, Turkey

Tel +904143183000

Fax +904143183190

Email kandemirhsn@yahoo.com
Aim: Obsessive-compulsive disorder (OCD) is a disorder characterized by the presence of obsessions and/or compulsions. Although disorder etiology and pathogenesis remains unknown, several theories about OCD development have been proposed, and many researchers believe that it is caused by both genetic and environmental factors. In the current study, our aim was to investigate miRNA levels in OCD.

Methods: In the current study, we evaluated miR18a-5p, miR22-3p, miR24-3p, miR106b-5p, miR107, miR125b-5p, and miR155a-5p levels in child and adolescent OCD patients. The research sample consisted of a group of 23 OCD patients and 40 healthy volunteer controls.

Results: There was no significant difference in age and sex between the two groups $(P>0.05)$. The levels of miR22-3p, miR24-3p, miR106b-5p, miR125b-5p, and miR155a-5p were significantly increased in the OCD subjects $(P \leq 0.05)$. There were no statistically significant differences in miR18a-5p or miR107 levels between groups $(P \geq 0.05)$.

Conclusion: There could be a close relationship between levels of circulating miRNAs and OCD. If we could understand how the signaling pathways arranged by miRNAs impact on central nervous system development, function, and pathology, this understanding could improve our knowledge about OCD etiology and treatment.

Keywords: OCD, micro RNA, miRNA, psychiatry, child psychiatry

\section{Introduction}

Obsessive-compulsive disorder (OCD) is a disorder characterized by the presence of obsessions and/or compulsions. Obsessions are recurrent intrusive thoughts, urges, or images that cause anxiety or distress, while compulsions are repetitive behaviors that are aimed at preventing or reducing anxiety or distress. ${ }^{1} \mathrm{OCD}$ may be chronic or have a periodic course, and significantly affects social and daily functions of patients. Although it was thought to be mostly evident in adulthood, studies in children and adolescents have shown a prevalence of OCD of $1 \%-4 \%{ }^{2,3}$ Publications reporting onset of OCD before the age of 6 years and treatment notifications are available. ${ }^{4,5}$ The coexistence of OCD and other psychiatric disorders is high. OCD is mostly associated with depression, tic disorder, and other anxiety disorders. More than $80 \%$ of patients diagnosed with OCD report that related symptoms began before the age of 18 years. ${ }^{6}$

In terms of symptoms, OCD is heterogenous in its clinical appearance. ${ }^{7}$ Phenotypic differences suggest that genetic, environmental, psychological, social, and biochemical factors are involved in the etiology. ${ }^{8,9}$ Genetic factors have been thought of as important in the development of OCD. ${ }^{10}$ It is estimated that OCD symptom heritability is between $45 \%$ and $65 \%$ in children, and between $27 \%$ and $47 \%$ in adults. ${ }^{11}$ Molecular genetic studies of OCD have usually focused on the monoamine pathway genes. ${ }^{12-15}$ 
These studies have implicated genes such as the catechol O-methyltransferase (COMT) gene, the serotonin $2 \beta$ receptor $(5 H T 2 B)$ gene, ${ }^{13}$ the serotonin transporter gene, ${ }^{14}$ the serotonin $2 \alpha$ receptor $(5 H T 2 A)$ gene, ${ }^{15}$ and the seven repeat of the dopamine D4 receptor (DRD4) gene. ${ }^{16}$

Several molecular genetic studies have aimed to determine the contributions of candidate genes to the pathophysiology of OCD. A study indicated that there was association of OCD hoarding type and a common single nucleotide polymorphism in the neurotrophin-3 receptor gene (NTRK3), which is regulated by micro-ribonucleic acids (miRNAs). ${ }^{17}$ miRNAs are evolutionally conserved small noncoding RNAs that regulate approximately $30 \%$ of human protein coding gene expression at the post-transcriptional level, and they play important roles in a wide variety of biological functions. ${ }^{18}$ miRNAs control gene expression by inhibiting translation or facilitating degradation of their target messenger RNAs (mRNAs). Computational predictions indicate that thousands of genes could be targeted by miRNAs in mammals. ${ }^{19}$ miRNAs are important for maintaining homeostasis at the neuromuscular junction. They also play an important role in synaptic plasticity in the central nervous system (CNS), and are involved in memory and mental retardation. ${ }^{20}$

The ability of miRNAs to affect the activity of all biological pathways may underlie some of the difficulties associated with linking psychiatric disorders to specific causative genes. ${ }^{21}$ The involvement of multiple signaling pathways in psychiatric disease complicates both the investigation of the underlying biological causes and efforts to identify effective therapies. Focusing on the roles of miRNAs in psychiatric diseases may lead not only to an explanation of the dysregulation of multiple pathways but also to novel therapies that can target entire gene networks. Perkins et al examined the expression of 16 miRNAs in the prefrontal cortex in subjects with schizophrenia or schizoaffective disorder and found decreased expression of 15 miRNAs in patients with schizophrenia. ${ }^{22}$ However, although miRNAs have been shown to be particularly abundant in the brain, their role in the development and activity of the nervous system remains largely unknown. In the present study, we evaluated miR18a-5p, miR22-3p, miR24-3p, miR106b-5p, miR107, miR125b-5p, and miR155a-5p levels in children and adolescents with OCD. In selecting miRNAs for the current study, previous literature pointing out the potential underlying neurobiology (enzyme, carrier molecule, receptor, etc) of the disease was reviewed, and potential most disease related miRNAs from the miRNA database (http:// mirbase.org/) were chosen. Table 1 shows the features of the studied miRNAs.

\section{Methods}

The research sample consisted a group of 23 patients from Harran University Faculty of Medicine Research Hospital, Child and Adolescent Psychiatry Clinic, who were referred to the clinic for the first time and were diagnosed with OCD, and 40 healthy volunteer controls. All patients were diagnosed with OCD by a child psychiatrist according to the Diagnostic and Statistical Manual of Mental Disorders, 4th Edition, Text Revision (DSM-IV-TR) ${ }^{23}$ diagnostic criteria, and they were treatment-naive. Patients with a history of cardiovascular disorders, epilepsy, diabetes mellitus, psychotic disorders, pervasive developmental disorders,

Table I Some of the features of the studied miRNAs

\begin{tabular}{|c|c|c|c|}
\hline miRNA & $\begin{array}{l}\text { Rationale for inclusion } \\
\text { in the current study }\end{array}$ & Previous studies' findings & References \\
\hline $\operatorname{miR} 18 a-5 p$ & $\begin{array}{l}\text { Believed to be involved in DNA damage } \\
\text { in OCD }\end{array}$ & Altered in DNA damage response & 24 \\
\hline $\operatorname{miR} 22-3 p$ & $\begin{array}{l}\text { Believed to regulate four candidate genes: } \\
B D N F, M A O A\end{array}$ & Found to be altered in panic disorder & 25 \\
\hline $\operatorname{miR} 24-3 p$ & $\begin{array}{l}\text { Believed to be related to oxidative stress, } \\
\text { which is a potential neurobiological } \\
\text { mechanism in OCD }\end{array}$ & $\begin{array}{l}\text { Found to be altered in oxidative DNA } \\
\text { damage and lipid peroxidation }\end{array}$ & 26 \\
\hline miR I06b-5p & $\begin{array}{l}\text { Believed to be related to oxidative stress, } \\
\text { which is a potential neurobiological mechanism } \\
\text { in OCD }\end{array}$ & $\begin{array}{l}\text { Downregulated in resveratrol treatment } \\
\text { that has antioxidant properties }\end{array}$ & 27 \\
\hline miRI07 & $\begin{array}{l}\text { Believed to be related to minimal brain change } \\
\text { in OCD }\end{array}$ & $\begin{array}{l}\text { Altered in traumatic brain injury and } \\
\text { neurodegenerative diseases }\end{array}$ & 28 \\
\hline $\operatorname{miR} 125 b-5 p$ & Believed to be related to hypoxia in OCD & Altered in high altitude sickness & 29 \\
\hline miRI55a-5p & $\begin{array}{l}\text { Believed to be related to inflammation which is } \\
\text { a potential neurobiological mechanism in OCD }\end{array}$ & Altered in inflammation & 30 \\
\hline
\end{tabular}

Abbreviations: BDNF, brain-derived neurotrophic factor; OCD, obsessive-compulsive disorder. 
or severe head injury were excluded. The healthy controls were recruited from a healthy child outpatient unit. After complete description of the study to the subjects, written informed consent was obtained from the parents, and assent was obtained from the children and adolescents. All of the study procedures were performed in accordance with the Declaration of Helsinki. The ethics committee of the Harran University Medical School approved the trial. Also, a semi-structured form was used to detect several sociodemographic and clinical variables of the patients. The final patient and control groups displayed similar distributions in age and sex. The current study was funded by the Harran University Board of Scientific Research Projects (funding number 12010). The current study was a cross-sectional study, and blood samples were taken once from both controls and OCD patients.

Total RNA was extracted from peripheral whole blood using Tri Reagent ${ }^{\circledR}$ (Sigma-Aldrich Co, St Louis, MO, USA). Reverse transcriptase (RT) reactions contained $5 \mu \mathrm{L}$ of extracted total RNA, $50 \mathrm{nM}$ stem-loop RT primer, $1 \times$ RT buffer, $0.25 \mathrm{mM}$ each of deoxynucleotide triphosphates, 50 units of modified moloney murine leukemia virus RT (Thermo Fisher Scientific, Waltham, MA, USA), 25 units of RiboLock ${ }^{\mathrm{TM}}$ RNase inhibitor (Thermo Fisher Scientific), and nuclease-free water to a total reaction volume of $15 \mu \mathrm{L}$. The reaction was performed on an automated thermal cycler (Veriti, Applied Biosystems, Foster, CA, USA), Real-time polymerase chain reaction (RT-PCR) conditions were sustained for 30 minutes at $16^{\circ} \mathrm{C}, 30$ minutes at $42^{\circ} \mathrm{C}, 5$ minutes at $85^{\circ} \mathrm{C}$, and then samples were held at $4^{\circ} \mathrm{C}$. Quantitativecomparative computed tomography $(\Delta \Delta \mathrm{CT}) \mathrm{RT}$-PCR was performed in an ABI Prism ${ }^{\circledR} 7500$ RT-PCR system (Applied Biosystems), using SDS version 2.0.6 software (Applied Biosystems). The specific primers and fluorogenic ZNA ${ }^{\mathrm{TM}}$ probes for the miRNAs were designed using Primer Express 3.0 software (Applied Biosystems), and these primers and probes are listed in Table 2. The stem-loop hsa-miR26b-5p was used as control according to the Applied Biosystems application note cms_044972. ${ }^{31}$ The mixed RNAs generated from the control group were used as a single reference sample. Primers and probes were purchased from Metabion International AG (Basel, Switzerland). The $25 \mu \mathrm{L}$ PCR mixture included $3 \mu \mathrm{L}$ RT-PCR product, $12.5 \mu \mathrm{L}$ of $2 \times$ TaqMan ${ }^{\circledR}$ Universal PCR Master Mix (Applied Biosystems), $900 \mathrm{nmol}$ of each primer (Primer F and Universal Primer R), and $200 \mathrm{nmol} \mathrm{TaqMan}{ }^{\circledR}$ probe. The reactions were incubated in a 96-well plate of pre-incubation conditions at $50^{\circ} \mathrm{C}$ for 2 minutes and at $95^{\circ} \mathrm{C}$ for 10 minutes, followed by 40 cycles at $95^{\circ} \mathrm{C}$ for 15 seconds at $60^{\circ} \mathrm{C}$ for 90 seconds. All reactions were run in triplicate. Relative expression of miRNA was calculated using the 2- $\Delta \Delta \mathrm{CT}$ method. The 2- $\Delta \Delta \mathrm{CT}$ method allows the calculation of the relative expression, which is the most common way to express this type of result. Higher $\Delta \Delta \mathrm{CT}$ values indicate lower expression rates.

The data were processed and analyzed using the statistical package SPSS 11.5 for Windows. Normality of the 2- $\Delta \Delta \mathrm{CT}$ values was checked by using the ShapiroWilk test. In the case of non-normal distribution, 2- $\Delta \Delta \mathrm{CT}$ values were expressed as medians, first quartiles (25th percentile), and third quartiles (75th percentile), and the comparison between groups was performed using the Mann-Whitney $U$-test. There are issues with using the Mann-Whitney $U$-test, especially in the context of gene expression data, as outliers may affect the results, and we are usually quite safe using the Mann-Whitney $U$-test. This test rank transforms and smoothes the data by reducing the effect of outliers. A box-plot graph was used to represent data distribution of miR18a-5p, miR22-3p, miR24-3p, miR106b-5p, miR107, miR125b-5p, and miR155a-5p variables according to the groups. Significant differences (two-tailed $P$-values) of $<0.05$ were regarded as significant.

\section{Results}

This study included 23 OCD subjects with a mean age of $10.60 \pm 2.06$ years (range, $7-16$ years) and 40 control subjects with a mean age of $11.25 \pm 2.93$ years (range, $7-17$ years). No statistically significant differences were detected in age and sex between the two groups $(P>0.05)$ (see Table 3 ).

The levels of miR22-3p, miR24-3p, miR106b-5p, miR125b-5p, and miR155a-5p were significantly more in the OCD subjects compared with controls $(P \leq 0.05)$. There were no statistically significant differences in miR $18 \mathrm{a}-5 \mathrm{p}$ and miR107 levels between groups $(P \geq 0.05)$ (see Table 4).

\section{Discussion}

To the best of our knowledge, this is the first study to evaluate miRNA levels in OCD subjects; therefore, we have chosen to discuss our findings in relation to other psychiatric disorders. We found increased miR22-3p, miR24-3p, miR106b-5p, miR125b-5p, and miR155a-5p levels in OCD patients compared with controls. In a study examining the relationship between miR18a and endogenous glucocorticoid receptor protein expression in rats, Uchida et al and Vreugdenhil et al suggested that levels of miR18a could be an important susceptibility mechanism for stress-related disorders. ${ }^{32,33}$ 


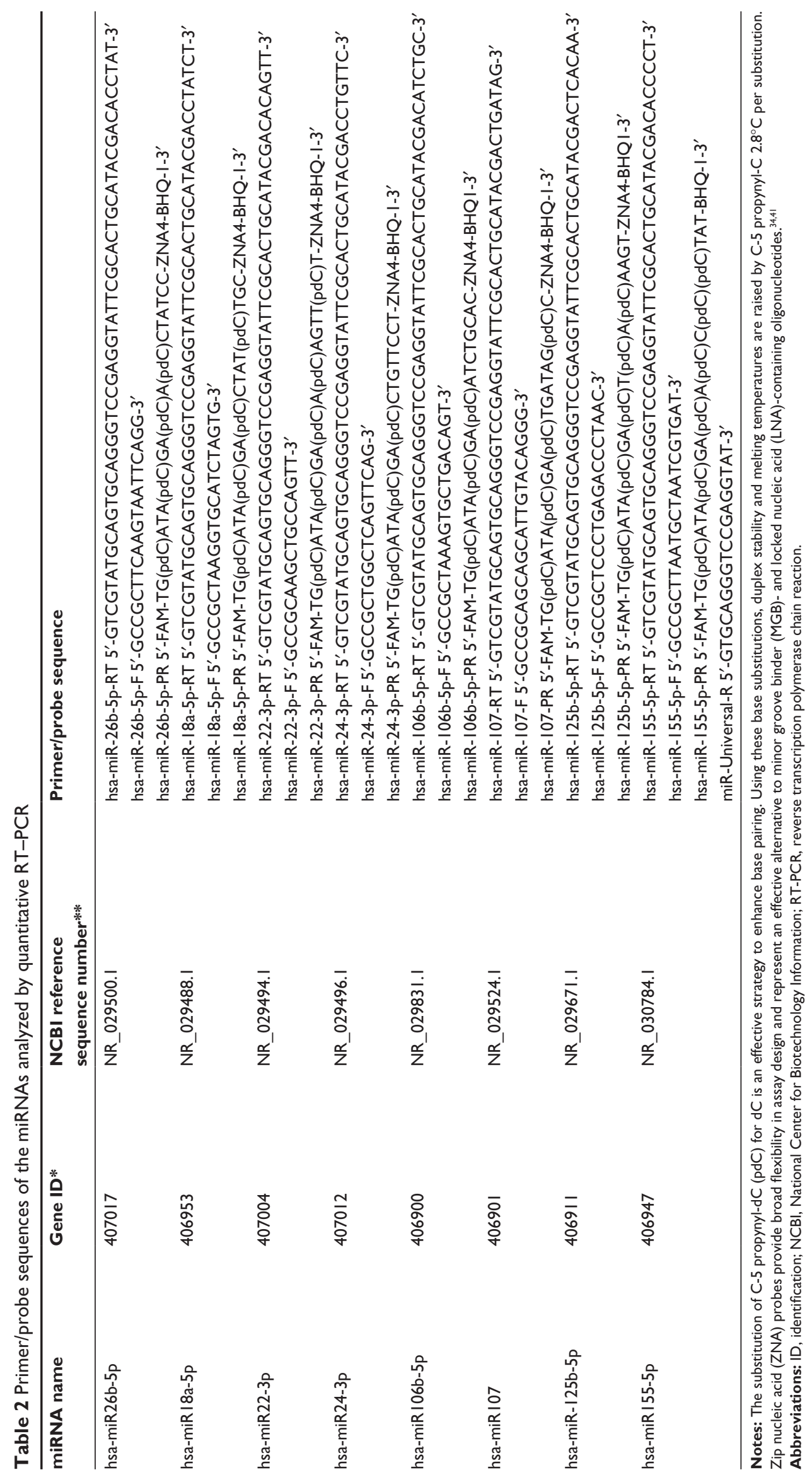


Table 3 Sociodemographic and clinical characteristics of OCD patients

\begin{tabular}{llll}
\hline & $\begin{array}{l}\text { OCD patients } \\
(\mathbf{n}=\mathbf{2 3})\end{array}$ & $\begin{array}{l}\text { Controls } \\
(\mathbf{n}=\mathbf{4 0 )}\end{array}$ & P-value \\
\hline Sex: male/female $(\mathrm{n})$ & $15 / 8$ & $26 / 14$ & $0.987^{*}$ \\
Age: mean \pm SD (years) & $10.60 \pm 2.06$ & $11.25 \pm 2.93$ & $0.374^{* *}$ \\
Age range (years) & $7-16$ & $7-17$ & \\
\hline
\end{tabular}

Notes: * $\chi^{2}$ test; $* *$ Student's $t$-test.

Abbreviations: $\mathrm{OCD}$, obsessive-compulsive disorder; SD, standard deviation.

Recent studies also reported an increase in the hypothalamicpituitary-adrenal axis activity in OCD patients. ${ }^{35,36}$

Muiños-Gimeno et al reported that miR22 was associated with panic disorder and that it regulated several candidate genes and related pathways involved in anxiety. ${ }^{25}$ In the Muiños-Gimeno et al study, miR22 was the miRNA with the highest number of functional targets, including the neurotrophic factor brain-derived neurotrophic factor and monoamine oxidase A genes, which are also potential targets in the neurobiology of OCD. ${ }^{37,38} \mathrm{~A}$ study performed in Turkey indicated that of OCD patients, $9.5 \%$ have co-morbid panic disorder. ${ }^{39}$ Moreau et al reported dysregulation of miR22 in schizophrenia and bipolar disorders. ${ }^{40}$ In our previous study, we found significantly decreased miR18a-5p, miR22-3p, miR24-3p, miR106b-5p, and miR107 levels and increased miRNA155a-5p levels in attention deficit hyperactivity disorder (ADHD) patients. ${ }^{41}$

In the current study, we found increased miR $155 a-5 p$ levels in patients with OCD compared with controls. A previous study reported miR155 dysregulation in patients with depression. ${ }^{42}$ Additionally, increased miR155 levels were reported in patients treated with lithium ${ }^{43}$ and increased miR155a-5p levels in ADHD patients. ${ }^{41}$ Rodriguez suggested that miR155 plays a key role in the homeostasis and function of the immune system. ${ }^{30}$ It was demonstrated that a wide spectrum of miR155-regulated genes, including cytokines, chemokines, and transcription factors. ${ }^{30} \mathrm{miR} 155$ was indicated to be induced in lipopolysaccharide-stimulated human monocytes. ${ }^{44}$ There has been mounting evidence that immune mechanisms may be directly implicated in the pathophysiology of some subtypes of OCD, such as pediatric autoimmune neuropsychiatric disorders associated with streptococcal infections. Clinical observation of the elevated frequency of obsessivecompulsive symptoms in patients with rheumatic fever, a post-streptococcal autoimmune disease, provoked the study of immune parameters in OCD. ${ }^{45}$ Konuk et al found that proinflammatory cytokine levels increased in OCD. ${ }^{46}$ miR 155 might therefore play role in inflammation in OCD.

Dysregulation of miR106b and miR24 levels has been reported in some psychiatric disorders including schizophrenia, bipolar disorder, and autism..$^{22,40,47-49}$ Researchers found that miR24 levels were increased in acute pancreatitis. ${ }^{50}$ It may be that miR24 levels are increased secondary to inflammation. Sarachana et al found that miR106b and miR107 levels were associated with autism. ${ }^{51}$

In the present study, we observed increased miR125b levels in OCD subjects. Eipper-Mains et al reported an association of miR125 levels and addiction disorders in mice. ${ }^{52}$ Additionally, miR125-5p levels have been studied in autism, Huntington's disease, and Alzheimer's disease. ${ }^{51,53-55}$ miR125-5p levels were also increased in hypoxia, ${ }^{29}$ which might be released during cellular damage. Understanding the signaling pathways affected by miRNAs in CNS development, function, and pathology could lead to improved therapies for treating heterogenic diseases.

Target genes for each miRNA and their potential neurobiological mechanisms are listed in Tables 1 and 2 . We think that DNA damage, oxidative stress, hypoxia, and inflammationrelated molecular mechanisms may be dysregulated in OCD. A study has revealed that aberrant expression of circulating miRNAs suggests potential diagnostic biomarkers of disease. ${ }^{56}$ There are 17 studies of neuropsychiatric disorders such as schizophrenia, bipolar disorder, and Alzheimer's

Table 4 Comparison of miRNA levels

\begin{tabular}{|c|c|c|c|c|c|}
\hline & \multicolumn{2}{|c|}{ Controls } & \multicolumn{2}{|c|}{ Patients with OCD } & \multirow[t]{2}{*}{$P$-value* } \\
\hline & Median & $25 \%-75 \%$ & Median & $25 \%-75 \%$ & \\
\hline hsa-miRI8a-5p & 2.0884 & $1.2391-3.4683$ & 2.2334 & $0.55 \mid 4-8.0329$ & 0.898 \\
\hline hsa-miR22-3p & 0.7023 & $0.2737-1.9575$ & 9.0235 & I. $1827-46.7572$ & 0.001 \\
\hline hsa-miR24-3p & 1.2362 & $0.547 I-2.0238$ & 2.1497 & $|.5132-6.991|$ & 0.004 \\
\hline hsa-miRI06b-5p & 1.8210 & I.I544-2.7I65 & 7.0767 & $2.6346-18.3542$ & $<0.001$ \\
\hline hsa-miRI07 & 1.9392 & $0.8819-4.5595$ & 1.9309 & $0.4692-5.6560$ & 0.775 \\
\hline hsa-miR I25b-5p & 1.6689 & $0.8125-4.5344$ & 7.2907 & $2.4899-40.1506$ & 0.002 \\
\hline hsa-miRI55-5p & 0.3331 & $0.1660-0.9977$ & $5.467 \mid$ & $1.66 \mid 4-8.2755$ & $<0.001$ \\
\hline
\end{tabular}

Notes: *Mann-Whitney $U$-test. Bold font indicates significant differences ( $P$-values) of 0.05 were regarded as significant. Abbreviation: OCD, obsessive-compulsive disorder. 
dementia showing peripheral miRNA changes, reflecting the CNS pathology in those diseases ${ }^{57}$ On the other hand, since psychiatric disorders including OCD are syndromes that not only affect the brain but also most of the body, peripheral changes are expected as well. For example, in OCD peripheral oxidative stress, biomarkers are shown to be altered, as in most of the other neuropsychiatric disorders, ${ }^{58}$ however, no blood test for OCD has yet been developed.

\section{Conclusion}

Our present study had several limitations, including the sample size, cross-sectional design, and the limited number of miRNA types. Moreover, the lack of previous studies in the literature regarding OCD and miRNAs prevents the comparison of our findings with previous studies. Despite these limitations, we believe our findings provide important groundwork for future studies.

In conclusion, understanding the dysregulation of circulating miRNA levels may improve our knowledge about OCD etiology and treatment. Our results should be regarded as preliminary until they are replicated.

\section{Acknowledgment}

This study was funded by the Harran University Board of Scientific Research Projects (funding number 12010).

\section{Disclosure}

The authors report no conflicts of interest in this work.

\section{References}

1. American Psychiatric Association. Diagnostic and Statistical Manual of Mental Disorders. 5th ed. Washington, DC: American Psychiatric Association; 2013.

2. Douglass HM, Moffitt TE, Dar R, McGee R, Silva P. Obsessive-compulsive disorder in a birth cohort of 18-year-olds: prevalence and predictors. J Am Acad Child Adolesc Psychiatry. 1995;34(11):1424-1431.

3. Flament MF, Whitaker A, Rapoport JL, et al. Obsessive compulsive disorder in adolescence: an epidemiological study. $J$ Am Acad Child Adolesc Psychiatry. 1988;27(6):764-771.

4. Coskun M, Zoroglu S. Efficacy and safety of fluoxetine in preschool children with obsessive-compulsive disorder. J Child Adolesc Psychopharmacol. 2009;19(3):297-300.

5. Garcia AM, Freeman JB, Himle MB, et al. Phenomenology of early childhood onset obsessive compulsive disorder. J Psychopathol Behav Assess. 2009;31(2):104-111.

6. Pauls DL, Alsobrook JP 2nd, Goodman W, Rasmussen S, Leckman JF. A family study of obsessive-compulsive disorder. Am J Psychiatry. 1995; 152(1):76-84.

7. Leckman JF, Bloch MH, King RA. Symptom dimensions and subtypes of obsessive-compulsive disorder: a developmental perspective. Dialogues Clin Neurosci. 2009;11(1):21-33.

8. Grisham JR, Fullana MA, Mataix-Cols D, Moffitt TE, Caspi A, Poulton R. Risk factors prospectively associated with adult obsessive-compulsive symptom dimensions and obsessive-compulsive disorder. Psychol Med. 2011;41(12):2495-2506.
9. Iervolino AC, Rijsdijk FV, Cherkas L, Fullana MA, Mataix-Cols D. A multivariate twin study of obsessive-compulsive symptom dimensions. Arch Gen Psychiatry. 2011;68(6):637-644.

10. Pauls DL, Abramovitch A, Rauch SL, Geller DA. Obsessive-compulsive disorder: an integrative genetic and neurobiological perspective. Nat Rev Neurosci. 2014;15(6):410-424.

11. Van Grootheest DS, Cath DC, Beekman AT, Boomsma DI. Twin studies on obsessive-compulsive disorder: a review. Twin Res Hum Genet. 2005;8(5):450-458.

12. Samuels J, Shugart YY, Wang Y, et al. Clinical correlates and genetic linkage of social and communication difficulties in families with obsessive-compulsive disorder: results from the OCD Collaborative Genetics Study. Am J Med Genet B Neuropsychiatr Genet. 2014;165B(4):326-336.

13. Mundo E, Richter MA, Zai G, et al. 5HT1Dbeta Receptor gene implicated in the pathogenesis of Obsessive-Compulsive Disorder: further evidence from a family-based association study. Mol Psychiatry. 2002; 7(7):805-809.

14. Hanna GL, Himle JA, Curtis GC, et al. Serotonin transporter and seasonal variation in blood serotonin in families with obsessive-compulsive disorder. Neuropsychopharmacology. 1998;18(2):102-111.

15. Walitza S, Wewetzer C, Warnke A, et al. 5-HT2A promoter polymorphism-1438G/A in children and adolescents with obsessive-compulsive disorders. Mol Psychiatry. 2002;7(10):1054-1057.

16. Cruz C, Camarena B, King N, et al. Increased prevalence of the seven-repeat variant of the dopamine $\mathrm{D} 4$ receptor gene in patients with obsessive-compulsive disorder with tics. Neurosci Lett. 1997;231(1):1-4.

17. Muiños-Gimeno M, Guidi M, Kagerbauer B, et al. Allele variants in functional MicroRNA target sites of the neurotrophin-3 receptor gene (NTRK3) as susceptibility factors for anxiety disorders. Hum Mutat. 2009;30(7):1062-1071.

18. Chekulaeva M, Filipowicz W. Mechanisms of miRNA-mediated post-transcriptional regulation in animal cells. Curr Opin Cell Biol. 2009;21(3):452-460.

19. John B, Enright AJ, Aravin A, Tuschl T, Sander C, Marks DS. Human MicroRNA targets. PLoS Biol. 2004;2(11):e363.

20. Corbin R, Olsson-Carter K, Slack F. The role of microRNAs in synaptic development and function. BMB Rep. 2009;42(3):131-135.

21. Bartel DP. MicroRNAs: target recognition and regulatory functions. Cell. 2009 23;136(2):215-233.

22. Perkins DO, Jeffries CD, Jarskog LF, et al. microRNA expression in the prefrontal cortex of individuals with schizophrenia and schizoaffective disorder. Genome Biol. 2007;8(2):R27.

23. American Psychiatric Association. (2000). Diagnostic and statistical manual of mental disorders (4th ed., text rev.). doi:10.1176/appi. books. 9780890423349 .

24. Song L, Lin C, Wu Z, et al. miR-18a impairs DNA damage response through downregulation of ataxia telangiectasia mutated (ATM) kinase. PLoS One. 2011;6(9):e25454

25. Muiños-Gimeno M, Espinosa-Parrilla Y, Guidi M, et al. Human microRNAs miR-22, miR-138-2, miR-148a, and miR-488 are associated with panic disorder and regulate several anxiety candidate genes and related pathways. Biol Psychiatry. 2011;69(6):526-533.

26. Morrow JD, Frei B, Longmire AW, et al. Increase in circulating products of lipid peroxidation (F2-isoprostanes) in smokers. Smoking as a cause of oxidative damage. $N$ Engl J Med. 1995;332(18):1198-1203.

27. Dhar S, Hicks C, Levenson AS. Resveratrol and prostate cancer: promising role for microRNAs. Mol Nutr Food Res. 2011;55(8):1219-1229.

28. Wang WX, Wilfred BR, Madathil SK, et al. miR-107 regulates granulin/ progranulin with implications for traumatic brain injury and neurodegenerative disease. Am J Pathol. 2010;177(1):334-345.

29. Buroker NE, Ning XH, Zhou ZN, et al. Circulating miRNAs from dried blood spots are associated with high altitude sickness. J Med Diagn Meth. 2013;2:3.

30. Rodriguez A, Vigorito E, Clare S, et al. Requirement of bic/microRNA-155 for normal immune function. Science. 2007;316(5824): 608-611. 
31. Applied Biosystems Application Note 2010: Publication 127AP11-01. Available from: http://www3.appliedbiosystems.com/cms/groups/ mcb_marketing/documents/generaldocuments/cms_044972.pdf Accessed August 26, 2014.

32. Uchida S, Nishida A, Hara K, et al. Characterization of the vulnerability to repeated stress in Fischer 344 rats: possible involvement of microRNA-mediated down-regulation of the glucocorticoid receptor. Eur J Neurosci. 2008;27(9):2250-2261.

33. Vreugdenhil E, Verissimo CSL, Mariman R, et al. MicroRNA 18 and 124a down-regulate the glucocorticoid receptor: implications for glucocorticoid responsiveness in the brain. Endocrinology. 2009;150(5): 2220-2228.

34. Paris C, Moreau V, Deglane G, Voirin E, Erbacher P, Lenne-Samuel N. Zip nucleic acids are potent hydrolysis probes for quantitative PCR Nucleic Acids Res. 2010;38(7):e95. doi:10.1093/nar/gkp1218.

35. Lord C, Hall G, Soares CN, Steiner M. Physiological stress response in postpartum women with obsessive-compulsive disorder: a pilot study. Psychoneuroendocrinology. 2011;36(1):133-138.

36. Kluge M, Schüssler P, Künzel HE, Dresler M, Yassouridis A, Steiger A. Increased nocturnal secretion of ACTH and cortisol in obsessive compulsive disorder. J Psychiatr Res. 2007;41(11):928-933.

37. Grados M, Sung HM, Kim S, Srivastava S. Genetic findings in obsessive-compulsive disorder connect to brain-derived neutrophic factor and mammalian target of rapamycin pathways: implications for drug development. Drug Dev Res. 2014;75(6):372-383.

38. Arrojo M, Baca-Garcia E, Perez-Rodriguez MM, et al. Platelet monoamine oxidase activity in obsessive-compulsive disorder. Eur Psychiatry. 2007;22(8):525-529.

39. Tükel R, Polat A, Ozdemir O, Aksüt D, Türksoy N. Comorbid conditions in obsessive-compulsive disorder. Compr Psychiatry. 2002;43(3): 204-209.

40. Moreau MP, Bruse SE, David-Rus R, Buyske S, Brzustowicz LM. Altered microRNA expression profiles in postmortem brain samples from individuals with schizophrenia and bipolar disorder. Biol Psychiatry. 2011;69(2):188-193.

41. Kandemir H, Erdal ME, Selek S, et al. Evaluation of several micro RNA (miRNA) levels in children and adolescents with attention deficit hyperactivity disorder. Neurosci Lett. 2014;580:158-162.

42. Smalheiser NR, Lugli G, Rizavi HS, Torvik VI, Turecki G, Dwivedi Y. MicroRNA expression is down-regulated and reorganized in prefrontal cortex of depressed suicide subjects. PLoS One. 2012;7(3):e33201.

43. Chen H, Wang N, Burmeister M, McInnis MG. MicroRNA expression changes in lymphoblastoid cell lines in response to lithium treatment. Int J Neuropsychopharmacol. 2009;12(7):975-981.

44. Liu G, Friggeri A, Yang Y, Park YJ, Tsuruta Y, Abraham E. miR-147, a microRNA that is induced upon Toll-like receptor stimulation, regulates murine macrophage inflammatory responses. Proc Natl Acad Sci USA. 2009;106(37):15819-15824.
45. Teixeira AL, Rodrigues DH, Marques AH, Miguel EC, Fontenelle LF Searching for the immune basis of obsessive-compulsive disorder. Neuroimmunomodulation. 2014;21(2-3):152-158.

46. Konuk N, Tekin IO, Ozturk U, et al. Plasma levels of tumor necrosis factor-alpha and interleukin-6 in obsessive compulsive disorder. Mediators Inflamm. 2007;2007:65704.

47. Beveridge NJ, Cairns MJ. MicroRNA dysregulation in schizophrenia. Neurobiol Dis. 2012;46(2):263-271.

48. Smalheiser NR, Lugli G, Zhang H, Rizavi H, Cook EH, Dwivedi Y. Expression of microRNAs and other small RNAs in prefrontal cortex in schizophrenia, bipolar disorder and depressed subjects. PLoS One. 2014;9(1):e86469.

49. Abu-Elneel K, Liu T, Gazzaniga FS, et al. Heterogeneous dysregulation of microRNAs across the autism spectrum. Neurogenetics. 2008;9(3):153-161.

50. An F, Zhan Q, Xia M, et al. From moderately severe to severe hypertriglyceridemia induced acute pancreatitis: circulating miRNAs play role as potential biomarkers. PLoS One. 2014;9(11):e111058.

51. Sarachana T, Zhou R, Chen G, Manji HK, Hu VW. Investigation of post-transcriptional gene regulatory networks associated with autism spectrum disorders by microRNA expression profiling of lymphoblastoid cell lines. Genome Med. 2010;2(4):23.

52. Eipper-Mains JE, Kiraly DD, Palakodeti D, Mains RE, Eipper BA, Graveley BR. microRNA-Seq reveals cocaine-regulated expression of striatal microRNAs. RNA. 2011;17(8):1529-1543.

53. Ghose J, Sinha M, Das E, Jana NR, Bhattacharyya NP. Regulation of miR-146a by RelA/NFkB and $\mathrm{p} 53$ in STHdh(Q111)/Hdh(Q111) cells, a cell model of Huntington's disease. PLoS One. 2011;6(8):e23837.

54. Wang WX, Huang Q, Hu Y, Stromberg AJ, Nelson PT. Patterns of microRNA expression in normal and early Alzheimer's disease human temporal cortex: white matter versus gray matter. Acta Neuropathol. 2011;121(2):193-205.

55. Cogswell JP, Ward J, Taylor IA, et al. Identification of miRNA changes in Alzheimer's disease brain and CSF yields putative biomarkers and insights into disease pathways. J Alzheimers Dis. 2008;14(1):27-41.

56. Huang Z, Huang D, Ni S, Peng Z, Sheng W, Du X. Plasma microRNAs are promising novel biomarkers for early detection of colorectal cancer. Int $J$ Cancer. 2010;127(1):118-126.

57. Maffioletti E, Tardito D, Gennarelli M, Bocchio-Chiavetto L. Micro spies from the brain to the periphery: new clues from studies on microRNAs in neuropsychiatric disorders. Front Cell Neurosci. 2014;8:75.

58. Kandemir H, Abuhandan M, Aksoy N, Savik E, Kaya C. Oxidative imbalance in child and adolescent patients with obsessive compulsive disorder. J Psychiatr Res. 2013;47(11):1831-1834.
Neuropsychiatric Disease and Treatment

\section{Publish your work in this journal}

Neuropsychiatric Disease and Treatment is an international, peerreviewed journal of clinical therapeutics and pharmacology focusing on concise rapid reporting of clinical or pre-clinical studies on a range of neuropsychiatric and neurological disorders. This journa is indexed on PubMed Central, the 'PsycINFO' database and CAS,

\section{Dovepress}

and is the official journal of The International Neuropsychiatric Association (INA). The manuscript management system is completely online and includes a very quick and fair peer-review system, which is all easy to use. Visit http://www.dovepress.com/testimonials.php to read real quotes from published authors. 